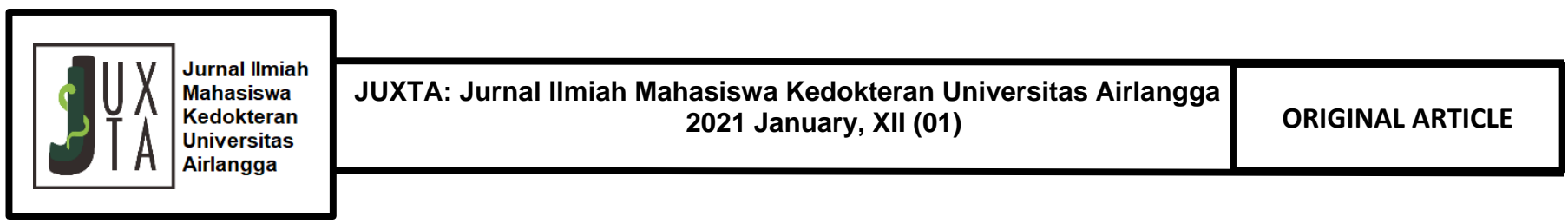

\title{
Prevalence of Pneumonia Severity in Children under 5 Years Old at Primary Health Care of Tambakrejo, Surabaya
}

\author{
Shofia Ihtasya ${ }^{1}$, Retno Asih Setyoningrum ${ }^{2}$, Deby Kusumaningrum ${ }^{3}$
}

\begin{abstract}
${ }^{1}$ Faculty of Medicine, Universitas Airlangga, Surabaya, Indonesia.
${ }^{2}$ Department of Pediatrics, Faculty of Medicine, Universitas Airlangga/Dr. Soetomo General Hospital, Surabaya, Indonesia. ${ }^{3}$ Department of Microbiology, Universitas Airlangga/Dr. Soetomo General Hospital, Surabaya, Indonesia.
\end{abstract}

\section{A B S T R A C T}

Introduction: Pneumonia is the world-leading cause of death in children under five years old and most prevalent in developing country. Proper initial diagnosis will determine further management, because pneumonia and severe pneumonia have different treatment. The aim of this study was to describe the prevalence of pneumonia severity in children under five years old at primary health setting.

Methods: This study was a cross - sectional descriptive study on medical records of children aged 2 to 59 months with pneumonia at primary health care of Tambakrejo, Surabaya from September to December 2017. Severity of pneumonia is classified using its clinical sign such as fast breathing, fever, chest indrawing, and general danger sign. The data were processed using Microsoft Office Excel and statistically analyzed with SPSS IBM 20.

Results: There were 31 respondents that were diagnosed with pneumonia at primary health care of Tambakrejo, Surabaya from September to December 2017. Most of the children diagnosed with pneumonia were aged 12 to 59 months (61.3\%) and $22.6 \%$ of the children had severe pneumonia.

Conclusion: Distribution of severity case of pneumonia at primary health care of Tambakrejo, Surabaya showed that there were more case of pneumonia with fast breathing than severe pneumonia or pneumonia with any general danger sign. Most of them were diagnosed at 12 to 59 months with a good nutritional status.

* Correspondence: retnoseodijo@yahoo.co.id

JUXTA: Jurnal Ilmiah Mahasiswa Kedokteran Universitas Airlangga

p-ISSN: 1907-3623; e-ISSN: 2684-9453

DOI: 10.20473/juxta.V12I12021.26-28

Open access under Creative Commons Attribution-ShareAlike 4.0 International License (CC-BY-SA)

\section{ARTICLE INFO}

\section{Article history:}

Received 12 November 2020

Received in revised form 28

November 2020

Accepted 14 December 2020

\section{Keywords:}

Severity,

Pneumonia,

Child,

Primary health care, 


\section{Introduction}

Pneumonia is the world-leading cause of death in children under five years old and most prevalent in developing country. ${ }^{1}$ In 2016, 880,000 children in the word died of pneumonia. ${ }^{2}$ The incidence of pneumonia in Indonesia is also quite high, there are 503,738 toddlers affected by pneumonia and 16,819 of them are diagnosed with severe pneumonia. ${ }^{3}$

Early case management of pneumonia is classifying the severity of illness using its clinical sign such as fast breathing, fever, chest indrawing, and general danger sign. Proper initial diagnosis will determine further management, because pneumonia and severe pneumonia have different treatment. Children with fast breathing according to age were classified into pneumonia and children who had fast breathing with any general danger sign were classified into severe pneumonia. ${ }^{4}$

Indonesian government had made a program to reduce the mortality of pneumonia, named Manajemen Terpadu Balita Sakit (MTBS). In contrast, mortality rate of pneumonia increased twice in 2016-2017 in Indonesia. Several risk factors such as leukocytosis, congenital heart disease, and severe pneumonia can increase under-five years old mortality due to pneumonia. ${ }^{5}$ Various factors including incomplete vaccination, low weight for age, and environmental behavior can also affect morbidity and mortality of pneumonia in children. ${ }^{6}$

Based on the previous explanation, it is important to conduct a research about prevalence of pneumonia severity in children under five years old, thus the government can evaluate prevention programs that are already underway. The aim of this study was to describe the prevalence of pneumonia severity in under five years old children at primary health setting

\section{Methods}

This study was a cross - sectional descriptive study on medical records of children aged 2- 59 months with pneumonia at primary health care of Tambakrejo, Surabaya from September - December 2017. A total sampling method was used. Variables in this research were severity of pneumonia, age, gender, and nutritional status.

Severity of pneumonia was diagnosed based on clinical symptoms of the patients, such as fever, tachypnea (according to age <2 month: $>60 \mathrm{x} /$ minutes; $2-11$ month: > 50x/minutes; $12-59$ months: $>40 x /$ minutes), and danger signs (drink difficulties, lower chest wall indrawing, stridor, cyanosis, so on and so forth). Severe pneumonia was diagnosed if the patient had danger sign. Data about nutritional status was obtained from weight per age, then it was classified into 4 categories, such as malnutrition, poor nutrition, good nutrition, and over nutrition.

Data collected were age, gender, severity of pneumonia, and nutritional status. The data were put into Microsoft Office Excel and statistically analysed using SPSS IBM 20. This study was approved by Medical Ethics
Committee of Faculty of Medicine, Universitas Airlangga, Surabaya, Indonesia.

\section{Results}

31 children were diagnosed of pneumonia from September to December 2017 at primary health care of Tambakrejo, Surabaya. The major severity of pneumonia patients were pneumonia (24 patients, $77.4 \%$ ) and mostly were male (18 patients, 58.1\%). There were 19 (61.3\%) children diagnosed with pneumonia at age 12 to 59 months. In severe pneumonia, the major characteristic were male (5 patients) and under 12 months (4 patients). Most of the children had good nutritional status (61\%). Table 2 shows the distribution of pneumonia patients based on their severity.

Table 1. Characteristics of pneumonia patients at primary health care of Tambakrejo, Surabaya in SeptemberDecember 2017.

\begin{tabular}{llll}
\hline No. & Characteristics & $\begin{array}{c}\text { Frequency } \\
\mathbf{n = 3 1}\end{array}$ & Percentage \\
\hline 1. & Age & 12 & $38.7 \%$ \\
& $2-11$ months & 19 & $61.3 \%$ \\
\hline & $12-59$ months & 19 & \\
\hline $2 . \quad$ Sex & 18 & $58.1 \%$ \\
& Male & 13 & $41.9 \%$ \\
\hline Female & Pneumonia Severity & \\
& Pneumonia & 24 & $77.4 \%$ \\
& Severe Pneumonia & 7 & $22.6 \%$ \\
\hline $4 . \quad$ Nutritional Status & 7 & $23 \%$ \\
& Malnutrition & 7 & $16 \%$ \\
& Poor nutrition & 5 & $61 \%$ \\
& Good nutrition & 19 &
\end{tabular}

Table 2. Characteristics of distribution of pneumonia severity in children under 5 years old at primary health care of Tambakrejo, Surabaya in September-December 2017.

\begin{tabular}{lll}
\hline Characteristics & \multicolumn{2}{c}{ Severity of pneumonia } \\
\cline { 2 - 3 } & $\begin{array}{l}\text { Pneumonia } \\
\mathbf{n = 2 4}\end{array}$ & \multicolumn{1}{c}{$\begin{array}{c}\text { Severe Pneumonia } \\
\mathbf{n = 7}\end{array}$} \\
\hline Age & & \\
2 to $<12$ months & $8(26 \%)$ & $4(13 \%)$ \\
12 to 59 months & $16(52 \%)$ & $3(9 \%)$ \\
\hline Sex & & \\
$\quad$ Male & $13(42 \%)$ & $5(16 \%)$ \\
Female & $11(35 \%)$ & $2(7 \%)$ \\
\hline Nutritional & & \\
Status & $5(16 \%)$ & $2(6 \%)$ \\
$\quad$ Malnutrition & $4(13 \%)$ & $1(3 \%)$ \\
Poor nutrition & $15(48 \%)$ & $4(13 \%)$ \\
Good nutrition & &
\end{tabular}




\section{Discussion}

This study showed that $61.3 \%$ of the children were diagnosed wit pneumonia at the age of 12 to 59 months. A study conducted in Nepal by Karki, et al. also revealed that most of the children were diagnosed with pneumonia at the age of 12-59 months. ${ }^{7}$ Another study in Jakarta and Bali showed different results. ${ }^{8,9}$ Both of them showed that the highest incidence of pneumonia was at the age of less than 1 year old. In developing country, most episode of pneumonia happened in children at age 0-4 years old with incidence rate 0.28 episode per year. ${ }^{10}$ Children under 5 years old have a weak body defense mechanism compared to adults, because their body is still growing and developing. ${ }^{8}$

This study showed that there were more male children waho were diagnosed with pneumonia (58.1\%). Previous studies that were conducted in Jakarta and Surabaya had a similar result. ${ }^{8,11}$ A study conducted in Jepara showed that male children were 1.4 times at risk for pneumonia. ${ }^{12}$ The reason for the conclusion of this study was the difference of immune system between men and women and also smaller diameter of the respiratory tract in men than women. ${ }^{12}$

This study showed that $61 \%$ of the children had good nutrition status. Another study in Padang showed similar result. ${ }^{13}$ A study conducted in Bali showed that nutritional status was a significant factor for severity of pneumonia in children $(p=0.02 ; 0 R=2.176) \cdot{ }^{9} \lg A$ has decreased in malnutrition, thus its function to protect the respiratory tract from incoming microorganisms cannot run well. Therefore, pathogens easily enter and increase the severity of the disease. ${ }^{14}$

This study showed that there were more cases of pneumonia than severe pneumonia cases. Previous studies that were conducted in Padang and Bali had similar results. ${ }^{13,15}$ Severity of pneumonia in children can be affected by various conditions from the host and the environment, such as overcrowding, low maternal educational level, biomass fuels for cooking, incomplete immunization, lack of exclusive breastfeeding, and malnutrition. ${ }^{16}$

\section{Conclusion}

Distribution severity case of pneumonia at primary health care of Tambakrejo, Surabaya showed that there were more case of pneumonia with fast breathing than severe pneumonia or pneumonia with any general danger sign. Most of them were diagnosed at 12 to 59 months with a good nutritional status.

\section{CONFLICT OF INTEREST}

The author stated there is no conflict of interest in this study.

\section{REFERENCES}

1. Organization $\mathbf{W H}$. Pneumonia is the Leading Cause of Death in Children. Geneva: World Health Organization, 2013.

2. Fund TUNCs. Pneumonia Claims the Lives of the World's Most Vulnerable Children. Dhaka: UNICEF, 2018.

3. Organization WH. Revised WHO Classification and Treatment of Pneumonia in Children at Health Facilities: Evidence Summaries. 2014.

4. Indonesia KKR. Data dan Informasi Profil Kesehatan Indonesia 2017. Jakarta: Kementerian Kesehatan Republik Indonesia, 2018.

5. Wulandari DA, Sudarwati S, Suardi AU, DM RG and Kartasasmita CB. Kematian Akibat Pneumonia Berat pada Anak Balita. Majalah Kedokteran Bandung. 2013; 45: 50-5.

6. Saha S, Hasan M, Kim L, et al. Epidemiology and Risk Factors for Pneumonia Severity and Mortality in Bangladeshi Children $<5$ Years of Age before 10-Valent Pneumococcal Conjugate Vaccine Introduction. BMC Public Health. 2016; 16: 1233.

7. Karki S, Fitzpatrick AL and Shrestha S. Risk Factors for Pneumonia in Children under 5 Years in a Teaching Hospital in Nepal. Kathmandu University Medical Journal (KUMJ). 2014; 12: 247-52.

8. Hartati S, Nurhaeni N and Gayatri D. Faktor Risiko Terjadinya Pneumonia pada Anak Balita. Jurnal Keperawatan Indonesia. 2012; 15: 13-20.

9. Artawan A, Purniti PS and Sidiartha IL. Hubungan antara Status Nutrisi dengan Derajat Keparahan Pneumonia pada Pasien Anak di RSUP Sanglah. Sari Pediatri. 2016; 17: 418-22.

10. Rudan I, Boschi-Pinto C, Biloglav Z, Mulholland K and Campbell H. Epidemiology and Etiology of Childhood Pneumonia. Bulletin of the World Health Organization. 2008; 86: 408-16B.

11. Hadisuwarno W, Setyoningrum RA and Umiastuti $P$. Host Factors Related to Pneumonia in Children under 5 Years of Age. Paediatrica Indonesiana. 2015; 55: 248-51.

12. Sunyataningkamto $S$, Iskandar Z, Alan R, et al. The Role of Indoor Air Pollution and Other Factors in the Incidence of Pneumonia in Under-Five Children. Paediatrica Indonesiana. 2004; 44: 25-9.

13. Nurnajiah M, Rusdi R and Desmawati D. Hubungan Status Gizi dengan Derajat Pneumonia pada Balita di RS. Dr. M. Djamil Padang. Jurnal Kesehatan Andalas. 2016; 5.

14. Rodríguez L, Cervantes $E$ and Ortiz R. Malnutrition and Gastrointestinal and Respiratory Infections in Children: A Public Health Problem. International Journal of Environmental Research and Public Health. 2011; 8: 1174205.

15. Baharirama MV and Artini IGA. Pola Pemberian Antibiotika untuk Pasien Community Acquired Pneumonia Anak di Instalasi Rawat Inap RSUD Buleleng Tahun 2013. E-Jurnal Medika Udayana. 2013; 6.

16. Hemagiri K, Sameena A, Aravind K, Khan W and Vasanta S. Risk Factors for Severe Pneumonia in under Five Children-A Hospital Based Study. Int J Res Health Sci. 2014; 2 : 47-57. 